This is the final peer-reviewed accepted manuscript of:

Pohl, A., \& Cuconato, M. (2021). Local Youth Policies between National Frameworks and Local Peculiarities: Examples from Two European Cities, Youth and Globalization, 3(1), 215-239. doi: https://doi.org/10.1163/25895745-03010009

Rights / License:

The terms and conditions for the reuse of this version of the manuscript are specified in the publishing policy. For all terms of use and more information see the publisher's website.

https://brill.com/page/RightsPermissions/rights-and-permissions\#selfarchiving 


\section{Local youth policies between national frameworks and local peculiarities: Examples from two European cities}

There are ongoing debates in youth research and politics about the impact of European and national youth policies at a local level. In the past decades, the European level has gained importance in these debates when, for example, the Council of Europe demands that the social task of youth transition to be supported through youth policy is "to enable young people to be active citizens socially as well as in the work life" (CDEJ, 2003: 12). To participate as an active citizen requires the autonomy to develop and express one's ideas and identity. This autonomy phase is also meant to acquire the necessary knowledge, skills and attitudes for their integration into society, a goal also promoted by the European Union's Youth Strategy and its prolongation proposed by the European Commission for the period of 2019-2027 (Smith et al., 2019). 'Integration into society' refers mainly to labour market integration, but also to their contribution to the development of civil society, and their active participation in community life and institutional democracy. This is a shift in European discourses which seem to have been dominated for a long time by a focus on labour market integration and a perspective of youth as either a problem or young people as victims of societal problems. It should be said that definitions and forms of youth policy vary across countries, within countries, and also over time, reflecting the value assigned to young people. Accordingly, policy-making approaches and methodologies range from regulation to emancipation, from prevention to intervention, from proactive to reactive, from problem-oriented to opportunity focused, from paternalistic to open. Applying one approach or another translates into very diverse measures, the rationale and implications of which play an influence on the decision of young people to participate or not in them. If they cannot have a say in the matters concerning them in terms of advising or co-deciding on policy design, contributing to service delivery, monitoring and evaluating their impact, they will not feel ownership of the decisions made, but alienation and refusal (Dahl et al., 2018).

While the shift in the European discourse aims to create participation opportunities for all young people, social changes and the upsurge of the economic crisis dating back to 2008 have even increased the traditional divisions implied in the condition of "being young" in different life contexts because of the different segmentation lines mirroring the general structures of inequality connected to family background, social class, ethnicity, gender and education (cf. Furlong \& Cartmel, 2007; Jones, 2009).

However, we can distinguish between two different definitions of the term youth policies. One notion defines them very narrowly as public offers of support and leisure activities for young people while other scholars argue for a broader understanding of the term as the ensemble of measures by public authorities addressing young people and including also the fields of social inclusion, labour market 
integration, education, training and health (cf. Walther et al., 2021; Loncle et al., 2020). A wider definition has the advantage to be able to focus also on the lack of public action or attention that would not be seen applying a narrow understanding of youth policies. It should be also noted that youth policies often define youth and their spheres of action thinking of them as "adult-in-becoming" and not as a "full status of being" in the society, justifying in this way the differential treatment in terms of their social power and recognition (Jones, 2009) and confining them in a limited number of public domains such as education, leisure, possibly volunteering, in which they are expected to participate in prescribed forms such as student councils and youth parliaments. In this article, however, young people are interpreted as full participants in the societies they live in at present and not in an indefinite future and who adopt a "biographical self-determination" in the public and/or through the use of the public institutions at their disposal. This implies that participation refers to potentially all young people's actions, individual or collective, being carried out in and/or addressing more or less formalized public spaces (cf. Walther, 2012: 240).

\section{Research question and methodology}

According to debates in youth studies and other fields of research, youth policies are still to be read as institutional expressions of aiming, planning and implementing youth-targeted actions that keep in mind the continuum of "perceived youth" either in term of the collective and positive representation of them (youth as a resource) or the opposite, an individualising and deficit-oriented perspective looking at youth either as potential perpetrators or victims (youth as a problem, see above). In this discussion, it remains unclear what impact European and national youth policies have on their implementation on the ground. Therefore, this article analyses the cases of two European cities with a similar history as hotspots of left-wing youth protests to shed some light on both the links between local youth policies and the national youth political frameworks and how young people in the two cities react - either appropriating or refusing them - in the light of their own interpretation of the principles and actions of the youth policies targeted to them.

Therefore, the two questions leading the analysis are:

1. How are local youth policies to be interpreted within the framework of national legislation concerning the youth question?

2. How do young people interpret the institutional efforts devoted to them through (local) youth policies?

To this aim, the present article concentrates on material deriving from two case studies conducted in Bologna/Italy and Frankfurt am Main/Germany (Anderson et. al., 2016; Lütgens et al., 2017) in the 
framework of a wider qualitative and ethnographic research (PARTISPACE) that took place in eight European cities, investigating the way and the places in which young people participate in public life (Walther et al., 2020a). Based on a discourse analysis of youth policies at national, regional and municipality levels (Becquet et al., 2020), mappings of local youth policies were conducted via 100 city walks with young people and 188 expert interviews. The core of the project was made of in-depth ethnographic case studies across 48 youth cultural settings in the eight cities. The ethnographic case studies were sampled for their variety of explicit and implicit links to urban public spaces and the potential for formal, non-formal and informal participation of young people in decision-making processes (see Walther et al., 2020b).

What we present here are the empirical findings on youth policy discourses as they emerged both in interviews with experts intended as privileged observers, who have a direct and deep vision of the youth policies and youth scene, due either to the role they play in a privileged position according to their professional roles (members of the municipal council, representatives of local authorities, youth workers, principals of secondary schools) or to their acting in a more informal way in youth setting (representatives of youth organizations, or youth activists) and in the assumptions of young people (aged between 15 and 30 years) from a variety of backgrounds (in schools, universities, vocational training, second chance schemes, youth centres and civil society initiatives) who are participating in some urban experiences identified either by experts or by young people themselves as participatory ones and that have been either planned and implemented directly within the framework of local youth policies or expressing a form of youth self-activation indirectly supported through the availability of premises and services included in them. Methodologically speaking, we analyse qualitatively collected individual and focus group interviews conducted in different youth participatory spaces taking place in two European cities, namely Bologna and Frankfurt. What these two cities have in common is the fact that they are both hosting huge universities attracting students from other regions of their respective countries due to their wealthy socio-economic structures and inspiring cultural and leisure-time scenes that have nurtured a tradition of alternative youth engagement.

The article is structured as follows: We are presenting findings from the two case studies starting with the main structures of youth policy in the two countries. In a second step, we analyse how they have been interpreted both by local administrations, their partners and the different segments of the youth population. To this aim, the empirical material collected in each city will be presented focusing on how these policies are appropriated by young people. Then, the paper aims at proposing a comparison on how youth policies work in these two urban contexts located in two very different national 
frameworks, showing differences and similarities, with the ambition of addressing different categories of young people.

\section{Youth policies in Italy and the Bologna case}

To understand what Bologna has represented and still represents in the field of innovation, promotion and implementation of youth policies, it is necessary to contrast it with the fragile and inconsistent panorama of national youth policies, their emergency approach on one side, and on the other side, the continuous struggle between the different left-wing city governments and the youth movements about the ownership of the ideological assumption of "being the true left". In the following, we present an overview of the development of the national youth policies counteracting them with their local development and the way in which young people have used them.

\section{The national framework}

Before the 1980s, the Italian government's approach to the youth question was limited to some welfare measures and campaigns against social and moral deprivation (youth as a problem). Until 1995, there was no systematic youth policy, but only laws on particular aspects of youth life, with responsibilities shared among different ministerial cabinets and no ministry or other equivalent institutional body to coordinate policies targeted at youth. This lack has a historical reason connected to the early postwar period, when the political forces decided to commit both education and transition to adulthood and professional life to the traditional educational actors (family, school, and church) and to the political organizations close to the party system (Montanari, 1996: 182-183), avoiding to take on the same comprehensive policies for youth and families adopted under the fascist regime.

However, in the 1980s, thanks to the devolution of power to the regions, the provinces and the municipalities, and as a consequence of the protests and social youth revolts in the late 1960s and the 1970s, local authorities undertook actions that, for the first time, were meant to integrate different levels of intervention, promoting the so-called "Progetti giovani" ("Projects for the youth") and direct involvement of young people and their associations. Throughout the 1980s and in the early 1990s, their commitment was reflected in the promotion of integrated systems of youth information offices known as Informagiovani, Youth Centres and Youth Councils that were supposed to help political decision-makers to develop guidelines for their actions.

Only since the late 1990s, national laws inspired by a more promotional vision have been approved. Still, this new perspective on youth has been weakened by the persisting absence of a coherent and implemented strategy both at national and local levels. 
However, two other aspects have to be underlined as persisting features of Italian youth policies. On the one side, there is the tendency to adopt measures under conditions of emergency (drugs, crime, bullying, unemployment) and so with pressure for quick, short-sighted and media-oriented solutions. On the other side, there is the prevailing supply of interventions in the field of leisure, music, culture and happenings, rather than towards the key factors for access to adulthood and full citizenship, like participation, income and job, housing, credit and right to study (Bazzanella \& Campagnoli, 2014), with the effect of strongly reducing and simplifying youth issues.

In 2006, the establishment at the national level of the Ministry for "Youth Policies and Sports Activities" (renamed in 2008 as "Ministry for Youth") represented an "unprecedented innovation" (Campagnoli, 2010). But still, Italy does not have any national general law on youth, any national agency for the development of youth policies, any national youth action plan or any national coordination of youth centres yet (Bazzanella \& Campagnoli, 2014). Furthermore, financial resources assigned to the National Fund for Youth Policies (established in 2007 with 130 million Euros) have constantly decreased in recent years, consisting of less than 33 million Euros in 2020 (www.politichegiovanili.gov.it). These data must be understood combining them with the poor resources descending from local resources: the municipalities, further weakened by the ongoing economic crisis started in 2008, make frequent budget cuts to youth policies (Andersson et al., 2016).

\section{Bologna: a complex relationship between the city and its youth}

Bologna is one of the most affluent Italian cities with a balanced economic structure mixing industry and services featuring high employment rates and high quality of life. Its University hosts about 90.000 students, mostly coming from outside the regional area of the city, essentially being a city in the city. However, the relationship between students and the city population often assumes the configuration of a forced and conflicting cohabitation because of the different lifestyles discording for what concerns the use and the rule of the public spaces (Piro et al., 2020).

The ability to develop concrete actions and intervene in favour of children and young people have made Bologna a reference point in Italy for the high-quality standard of services devoted to them, while offering a fertile environment for the development of youth participation (Jäggi et. al., 1977; Colombo \& Vanelli, 2012).

Since the end of the war, Bologna has been led by the PCI (Communist Party of Italy) and by centreleft parties after its dissolution and the city is, hence, characterised by this clear political identity, finding its legitimation in the national history bound to the Resistance and the construction of liberaldemocratic republican institutions, and influencing the local participatory scene, animated by clubs, 
associations, committees linked to the left-wing scene. At the same time, it is worth mentioning that the city also nourishes the civic activism of Catholic faith groups promoted through the parishes, the scout groups and the different voluntary associations of Catholic inspiration (Donati et al., 2002).

The post-war period has witnessed in Bologna the so-called "fever of doing" (Dozza, 1987) animating the "Bolognesi" in rebuilding their destroyed city. In that context, youth participation was nourished by the enthusiasm of reconstructing the democratic political system, having the chance to engage politically in territorial activities in the neighbourhood's committees, which emerged from the decentralization of the municipality's power to districts and the participated planning and activation of social services (subsidiarity principle). At the core of the communists' political intervention, portrayed as a "virtuous example of effective collaboration between the civic and political aspects of a modern community" (Baldissara, 1994: 225) were the welfare policies (health services, nurseries and prep-schools) that the local PCI had implemented since the 1950s. Welfare services expanded far more rapidly than in any other city, to the extent that Bologna's administrators could boast that 9095\% of Bolognesi aged 3 to 6 years now had a nursery place (Troilo, 2013).

However, the affection between the city and its youth knew the first crisis during the student mobilization that also began to take off in Italy in 1967, and the movement continued right through the 1970s. The Bologna University was occupied and alternative lifestyles began to dominate youth culture, questioning the rigid orthodoxy, work ethic and conformist lifestyle of the party's members (Capponi, 1989; Rapini, 1999).

In the second half of the 1970s, high unemployment rates struck younger generations in particular, who were furthermore confronted with a politics of austerity and sacrifices that clashed with their evolving lifestyles and consumer attitudes. The new protest movement was more concerned with existential and personal issues than with revolutionary, political ideals, and explicitly rejected the Communist Party's rigid public and political ethics promoting its ideals of work and social sacrifice. Although the relationship between the alternative left-wing milieu and the political parties of the left had worsened throughout the 1970s, the youth movement felt dramatically the PCI's "historic compromise" with the Christian Democrats, taking place in 1976 — an alliance forged in the name of stability that they judged as an unforgivable concession to the ruling class, betraying the young, precarious, and marginalized subjects of the society. However, in Bologna, the turning point of the conflict was the death of the young activist Francesco Lorusso (1 $1^{\text {th }}$ of March, 1977), who was shot during clashes between students and police. This event signed the decisive political rupture in the prosperous "red city" with an international reputation of "Isola felice" ("happy island"). It happened, that despite its far-reaching reforms, Bologna's PCI had fatally ignored the revolutionary orientation 
of the city's young people, who since then started to engage in "alternative" political practices involving squatting in vacant buildings to protest the shortage of affordable housing and the set up of alternative spaces known as "social centres". This period reflects a "withdrawal of [literary-political] commitment to macro-political, left/right-wing ideologies, in favour of micro-political, communitybased initiatives" (Burns, 2001: 1).

The Municipality reacted to regain the favour of young people by promoting a "youth project" aimed at involving them in the civic, political and economic life of the city through the creation (or requalification) of youth centres in each district, the promotion of cultural events connected to youth counter-cultural consumption (the punk-concert of The Clash in the main medieval square of the city that was boycotted by local punks themselves remains famous) and the special agreements signed with those groups of young people (e.g. cooperatives, associations) who offered to recover run-down buildings owned by the city.

However, despite the institutional efforts, from the 1990s onwards, youth participation in Bologna has been mainly catalysed by the activities of the many "centri sociali" developing in the city usually following a squatting action that has led, depending on the political "climax" either to a police eviction or to a formal agreement with the Municipality for the use of the squatted building. Mainly extra-parliamentary left groups-oriented, the "centri sociali" of Bologna enliven the city through both protest actions and civil campaigns and art and cultural events (theatre workshops, jam session) throughout the 1990s and resist still today. To testify that Bologna continues to be one of the most Italian active cities on the political and civic sides, thus unconventional, it is enough to recall the recent student movements expressing their discontent towards the educational policy promoted by the government and the so-called "Sardines" movement that, starting with a flash mob on the $14^{\text {th }}$ of November 2019, organized in Piazza Maggiore, the main square of Bologna, spread through the whole country a series of peaceful demonstrations to protest against the right-wing surge mounting in the country and, more specifically, against the political rhetoric of the former right-wing Interior Minister, Matteo Salvini.

It should be however underlined that in the last ten years, the upsurge of the crisis and consequent austerity measures adopted by the Municipality have negatively impacted its still high level of services and provision. In fact, according to the $31^{\text {st }}$ Inquiry on the country's wellbeing in 2020 , Bologna still tops the ranking of Italian cities for Quality of Life (Casadei \& Finizio, 2021). However, the youth unemployment rate has significantly increased, penalizing young people more than the rest of the population. The welfare state has been strongly cut and huge housing problems (inadequacy, cost) have emerged in the public debate and the lack of flats or rooms has fostered other illegal 
occupations conducted by new actors (immigrants, low income evicted subjects and families), which in several cases, have brought the local institutions to a repressive reaction. These elements have deepened the wave of youth resentment, disaffection and distrust towards the Municipality.

\section{Local youth policy structures}

Nowadays, youth policies in Bologna are developed in the framework of national and regional guidelines, focusing on six main areas regarding support for employment, innovation and creativity; social inclusion; culture and education and the transition from school to work, welfare and health citizenship and participation (Colombo \& Vanelli, 2012)

Young people's access to the civic and political opportunities of the city is promoted through projects coordinated by the local administration that through its well-rooted principle of subsidiarity (see above), acts as the principal networking agent for schools, third sector agencies, volunteering and young people associations. In the vision of the Municipality, all these actors should network the best energies of the city in favour of the younger age groups of the population, with particular attention to the issues of education and culture.

Among the different projects, "Investing in diversity" supports a renewal of the intercultural dialogue through the creation of a regional network of intercultural centres. In the framework of the "Off the Wall" project, young people and adolescents at risk of exclusion are involved in pieces of art education that use the public space as a common good, engaging the youngster in the "embellishment" of the city while promoting their self-esteem as their artefacts can be seen and admired by the citizens. The Municipality is also engaged in raising awareness about the phenomenon of school dropout, activating synergies among the different educational providers in order to map the existing realities and to address it grounding on contextual data.

\section{Different perspectives of experts and young people on participation and youth policy}

According to a public manager in charge of the "youth policies project", Bologna has always tried to promote the development of youth participation, usually demonstrating a certain receptiveness in relation to the instances of engagement coming from the young people themselves. Local institutions adopt youth policies that - according to the subsidiarity principle - support youth's experiences of self-activation in cultural, sports and civic activities either by small funds or by providing (abandoned) spaces.

However, the funder of an association dealing with youth engagement, social inclusion and social cohesion projects remarks how, despite some successful initiatives "youth policies as a whole lack an adequate coordination and a shared vision". Along this line, some youth workers, members of the 
neighbourhood committee of a wealthy district remark that "over the last few years, despite the increasing institutional use of the word participation, real participatory decision-making processes allowing young people to engage without pre-defined dynamics and outcomes have been decreasing". Moreover, some members of an association organizing cultural events aimed at the re-appropriation of the public space recognise that in the actions developed by the Municipality, both quantitatively and qualitatively, young people and students are less represented than other age groups. A former activist, president of an association providing consultancy for schools and youth workers speculated an explanation. According to him, they perceive that "institutions do not intend 'participation' as a real delegation of decisional power that substantially remains in their hands. What they do, is a formal opening to people consultation resulting in a 'capture' of intellects, works and competencies". Therefore, young people adopt self-activation forms in order to avoid the manipulation and expropriation of their ideas.

In a focus group discussion, a university group of students coming from outside Bologna claims that the city "is not as tolerant and solidarity oriented anymore as it was". Social policies have been cut in favour of profit-oriented policies and downtown gentrification. They feel that their presence in the University area is seen more and more as a problem. According to them, this is evidence that "over the years, Bologna has turned hostile (has become embittered)", closing the door to the innovation's potential of young people.

A young representative of the Bolognina District presents another side of this hostility: "More and more Bologna's city life is organised in and around the city centre, especially the nightlife. Thus, young people living in the suburban districts feel excluded and left to themselves as they are segregated from the city centre where almost everything happens". This suggests that social inequalities and spatial distance to the city centre, as well as to youth policy offers, reproduce each other mutually. Moreover, according to the chairperson of a non-profit film-making organization "the spaces in which young people can express their creativity have decreased in the last few decades and actually the self-organization of events and project is much more complex and bureaucratic, involving a lot of complicated rules, details, and processes". The interviewee states that this is happening "simultaneously to an increased rhetoric on the importance of youth participation".

According to the before-mentioned students association, institutions just "manage" participation in order to "govern" phenomena that, otherwise, would turn social problems into open conflicts. Students further complain that the engagement of the radical left groups in squatting actions in favour of migrants and poor local homeless families has brought on a series of police evictions exacerbating the relations between youth and local government. The squatting actions aiming at raising awareness 
among institutions and public opinion on the housing issue are neither at institutional nor at the level of public opinion recognised as political engagement. What emerges through the focus groups with young people is that the institutional promotion and policies of youth participation and participation experienced and lived by themselves do not coincide anymore. Young people blame the Municipality for its intentional handling of participation's "promotion" as a way to "manage and govern" the instances of engagement expressed by young people themselves, systematically avoiding a "real bottom-up process of power's redistribution and control". An emerging - unexpected - effect of this disillusion is the instrumental use that, on their side, young people make of the opportunity emerging from youth policies, in terms of funding, spaces and services, living their relationship with both politics and institutions as a "liquid" one, without those long-lasting belongings connecting in the past Bologna's generations, politics and social context.

\section{Some concluding remarks}

In Bologna, different actors, diffused along different settings, promote youth policies that in the vision of the Municipality should network in order to support young people, especially in the fields of education and culture. However, despite the interest and responsiveness that institutions and political actors exhibit, a large part of local youth engagement takes place outside the conventional civic and political arenas, that in Bologna are still very structured and requiring a long-lasting engagement that does not correspond anymore to young people's preferred forms of activation (Della Porta, 2015). It's not by coincidence that in Bologna, the last Youth Council experiment dates back to 1998: after the election, the representatives met four or five times in empty rooms and therefore decided to resign their mandate and since then, the Municipality has opted to pursue more youth-oriented ways of intervention. The lacking interest of the young "Bolognesi" for this formal expression of participation does not in any way mean that they do not want to have a say in the public scene. In fact, young people are often at the forefront of civic and political activism: local youth associations campaigning for a specific "cause" and the actions of the "centri sociali" in favour of the most vulnerable populations of the city (migrants, homeless, evicted people) are just two of the many experiences of youth engagement animating the everyday life of the city.

A finding of our fieldwork is that these actions are mainly self-activated and self-managed by young people themselves, who like to be authors, managers and promoters of engagement activities assuming either the forms of youth associations and organizations or remaining at the level of informal groups. In this last case, participation as a deeply militant way of interpreting politics and commitment to the emerging social problems of the city, acquires a conflicting character giving rise 
to institutional blaming discourses and consequently repressive reactions against young people's groups.

In this paradoxical framework, showing a youth responsive city as an apparently deaf institution to the demands of its younger generations, some interviewed young people and experts (see above) argue that youth policies in Bologna work but do not foresee a real delegation of decisional power. This means that are the reflections of the different institutional representations of youth, which guide the way in which they are planned, funded and therefore implemented, depending on how a certain youth group is perceived as either a resource for the city or a challenging burden for its present and future development. Bologna also appears as a city that marginalizes both the alternatively politicized groups of students, and those young people who live outside the city centre. This "negative trend in a positive context" (described as "the end of the golden age of Bologna as a city of opportunities" by a young representative of the Bolognina district) is one of the emerging issues of our work and seems to be lived as a problem by most of the interviewed young people.

Reflecting on the section presenting the Youth Policy Structures, it could be argued that the Municipality tries to respond to the "supposed" needs of the (at least) three different youth populations coexisting in the city neglecting the opinions, desires and needs of their supposed target groups identified top-down: the nearside young people born and who ever lived in Bologna, the Italian students and workers coming from other areas, and those young people with migrant origin. To do this, it adopts different approaches - going from the compensatory's measures aimed at closing the “institutionally" perceived young people's deficits to the proactive measures aimed at promoting the promising youth talents. On their side, those groups have chosen to live differently in the city, in a sort of tribalization of the space ("just the students", "just the hipsters", "just the squatters") and use differently the room for manoeuvre inherent in the youth policies, appropriating them in very different ways: showing antagonism to the city administration as the central mechanism adopted by the most politicized students, withdrawal due to the social stigma lived by the most vulnerable groups, and acceptance by the ever born, middle class upper secondary and university students, who are able to use the cultural and educational services at their disposal.

In order to overcome the "communication's short circuit" between institutional youth policies and the engagement of young people, it would be helpful to recognise the several gaps causing it: the thematic gap, as the issues of the policies are not necessarily top priorities for young people, the cultural gap, as the mechanisms of youth policies are too slow and the language in which they are expressed often does not fit in the youth cultural framework, the technological gap, meaning the way 
in which today young people discuss and decide to engage, and the generational gap in terms of decision-makers in charge of youth policies, who are adults and think like such.

\section{Youth policies in Germany and the Frankfurt case}

\section{The national framework}

The term "youth policy" in Germany is frequently interpreted as limited to youth organizations and out-of-school activities, disconnecting it politically from education/training and employment. However, the welfare system includes a highly differentiated array of policies specifically targeted at the support of children and youth. It is made compulsory by the Federal Children and Youth Aid Act of 1991, but funded and implemented largely by the municipalities. The areas covered by the Children and Youth Aid Act include public childcare, which has become one of the areas with the most investment in the past ten years due to a new guarantee to childcare for children between 3 and 6 years of age. Public care covers a variety of measures from community-based family support to foster care. Child protection also includes care for young offenders and the regulation of adoption.

The scope of youth policy thus encompasses welfare for all citizens and specialised care for individuals in need. However, German youths are disadvantaged by labour market policies, in particular those concerning unemployment benefits. A basic problem to this can be traced back to the education system, where the three-tier school system leaves a distinct group without the necessary skills to compete in the highly qualified segments of the labour market. But there are many young unemployed who lack the necessary requirements for the means-tested job-seekers allowance and they must rely on the basic insurance, which is family-based. The result is that people under 25 who leave their parents' household lose their benefits. Furthermore, sanctions for unemployment under national activation schemes hit young people harder, out of a belief that young people can be reeducated through harsh measures. This structure fits neatly with Walther's theory on employmentcentred regimes (Walther, 2006), where much of German citizenship hinges on employment. Young people are thus dependent on their parents until they gain employment for themselves, which hinders them in transitioning to adult life.

Youth work in Germany is a special part of the youth service. It is offered to all young people until the age of 27. Youth work differs explicitly from other offers and parts of the youth services. The aim of youth work is to offer young people developmental and educational experiences based on their voluntary involvement. The idea is to enable them to play a part in the democratic society and learn the meaning of citizenship. The professional discourse on youth services focuses on the support for young people to develop their own values, attitudes and capacity to critically analyse society and see themselves in their context. Youth work was and is seen as an important part of democracy education, 
emancipation and participation. In the more narrow sense, youth work has several branches: The law first distinguishes between Open Youth Work and Youth Social Work. While the first is more preventative/promotion oriented and supports measures such as youth centres and associative youth work, mainly provided by youth associations such as the scouts, church- and interest-related groups, the second is more problem-focused and consists of support measures for social inclusion such as outreach work or guidance and training measures.

\section{Frankfurt: a global city between high towers, immigration and left-wing movements}

Frankfurt am Main has a total population of roughly 740.000 people. Among the cities in Germany, it has the highest proportion of inhabitants with a migration background and $90 \%$ of the workforce is employed in the service sector. The gross domestic product was around $79.000 €$ per inhabitant per year, which is one of the wealthiest cities in Germany with its average income per capita of about $43.000 €$, which coincides with one of the highest levels of costs of living in Germany. ${ }^{1}$ Despite this, Frankfurt with its red-light district is labelled as a crime city with one of the highest crime rates among German cities (more than 16.000 per 100.000 inhabitants). ${ }^{2}$ This stands in high contrast to the high share of well-educated inhabitants with one of the highest shares of pupils who are visiting the grammar schools in Germany and the highest number of pupils with a migration background visiting grammar schools.

As a stronghold of the 1968 movement, Frankfurt played a central role reflected by many squatting and a highly politicised student-population (Mullis et al., 2016). An important role in this was played by the institute of social research, the so-called Frankfurt School (Frankfurter Schule). Although it is different identifying direct lines of tradition in this respect, the political life of Frankfurt is still characterised by a broad and visible left-wing scene but also considerable right-wing groups. Apart from this, ideas, practices and styles of the 68-movement have also influenced for many years actors and activities in youth welfare and youth work sectors where Frankfurt was one of the hot spots of two of the most marking movements for youth policies in Germany - the "Heimkampagne" ("campaign against foster homes", see Steinacker, 2017) and the "Jugendzentrumsbewegung" ("Youth centre movement", see Templin, 2015).

\section{Youth policy structures}

On the level of youth policies, Frankfurt is less of an exception among other cities in Germany than Bologna is among Italian cities as the policies for young people are deeply marked by its central focus

\footnotetext{
${ }^{1} \mathrm{http} / / /$ www.wiwo.de/politik/deutschland/staedteranking/

${ }^{2} \mathrm{http} / / / \mathrm{www}$.fr-online.de/kriminalitaet/kriminalitaet-so-gefaehrlich-ist-frankfurt-wirklich,25733026,26580782.html 14
} 
on "children and youth welfare" like in other German cities. This section will show that this focus does not only pertain to public and professional debates about youth or the weight of budget lines in public funding. Seen from an international comparative angle, this also influences the way participation is framed by the legal framework of youth policies. For instance, when we look into the "Children and youth welfare act", we can see that procedural rights are running through this law. With procedural rights, we are summarizing all participation rights in statutory acts and service provision, which are often not granted to children and young people but to their parents and carers. Participation in other aspects such as taking part voluntarily is endemic to open youth work. This faction of publicly funded youth services in Germany as in many other European countries have been under stress for more than a decade now: New public management and other forms of restructuring the welfare state have had a huge impact on the structure of youth work provision. The large shift of public resources towards all-day schooling and daycare for small children has shifted both public and professional attention. For the context of the city of Frankfurt, this development can be traced down to the shifts in the budget of the Municipality where the budget for open youth work has been capped and most of the planning of children and youth infrastructure has moved from the youth department to the department for education. So, childhood has gained momentum as a policy focus while youth matters have been somehow marginalised (Lütgens et al., 2017).

The Frankfurt Youth Council is an important actor of youth participation in Frankfurt and was founded in 1920. The council was reorganized after World War II and at the beginning of the 1950s, a new "House of Youth" was built. Nowadays, the council acts as an umbrella organization for 29 youth organizations that operate children and youth work and children and youth policy in Frankfurt. Further, the youth council is a point of intersection for the diverse and wide work of their member associations: it serves as a communication platform between the youth organizations ensuring cooperation among them, which have representatives in the local youth welfare committee (Jugendhilfeausschuss) and their expert committees (Fachausschüsse). Furthermore, they are members of the District Youth Education Centre (kommunales Jugendbildungswerk) with a focus on political and cultural education. So, it perfectly matches the decision-making structures of the representative democracy in Germany with a strong role of civil society organizations and the corporatism related to the strong subsidiarity principle between statutory and civil society actors.

Open Youth work originates from the beginning of the 20th century. Since the 1970s it is understood as a social infrastructure for all young people based on principles of participation and selforganization and as an area of youth welfare separated from youth organizations. Nowadays, Frankfurt is well equipped with its 130 organizations of open youth work. There are 69 youth centres 
or clubs. Those youth centres, youth associations and other organizations offer young people an array of opportunities to realise their own projects or ideas and furthermore to develop their own interests, learning participation, self-organization and mediation of social participation rights. A particular feature of Frankfurt is that the majority of these youth organizations are under the responsibility of voluntary youth (welfare) organizations.

Other important actors include the Frankfurt children's office working to support children to realise ideas concerning their environment and making the city of Frankfurt less bureaucratic. Then, there is the "Pupils and students council Frankfurt" (Stadtschüler_innenrat Frankfurt)), which is a local council for pupils that has been very active in current youth policy discourses. In addition to these formal participation structures, Frankfurt is characterised by a relatively large number of groups and movements of political self-organization on the left of the political spectrum as well as on the right political or religious motivated spectrum. The leading democratic parties also have youth sections.

When it comes to funding, there is a notable shift of resources from youth work into youth social work, especially school social work. An analysis of the current political and practical development reveals that the available resources are less invested in spontaneous and open offers (for example, open youth work), but in problem-, school-, and labour market-orientated offers respectively youth work is exploited for school and labour market (Walther, 2014; Schwanenflügel \& Walther 2015).

The open youth work is also increasingly orientated towards school-education and the labour market. In this way, open youth work has lost an increasingly part of its structures of openness and voluntariness. At the regional level, the Hesse government has significantly reduced benefits to the social sector. This has resulted in the creation of an alternative structure of cooperation between the providers of youth welfare services. There is also a Hessian Municipal Code that regulates responsibilities, rights and authorities in the municipalities, which supports the involvement or consultation of children and young people in relation to youth issues. However, the formulations are very vague and this reflects the weak political position that both young people's participation and youth work have in the Hesse region.

\section{Different perspectives on youth policies}

The shift in policies for young people has brought about a shift in public and professional discourses as well. The general ideological shift away from distributive justice towards equality of chances as the core of the German welfare state has re-centred the focus on how young people are addressed by policies and services. It can be argued that there is a shift in these towards addressing young people as holders of "human capital", looking at youth as a life stage devoted to the accumulation of 
educationally generated capital and the preparation for something in the future (Schwanenflügel \& Walther, 2016). It comes as no surprise that in our interviews the experts neither use the term "youth policy" nor did they refer to important events or key persons in its local history. And although there is a youth policy planning unit within the Municipality, it remains a marginalised issue in local politics according to the experts.

At the same time, within this given shift of addressing young people merely as students or pupils, both the experts and young people we have interviewed deplore a lack of "free" spaces, in which young people are not situated within a pedagogically framed environment. They claim the city does not offer enough spaces that are open to appropriation. Instead, most spaces young people encounter are described as "functionalized". Or, as one girl put it in a group discussion, "most spaces are speaking for themselves" as in 'it is evident what you have to do there, it needs no explanation'. A school is a school, a sports ground is a sports ground.

On the subjective maps of the city drawn during the focus groups with young people, this perception is already widened - when places like the own neighbourhood come into the focus or in the discussion of these maps, public places are assigned different meanings depending on the social status of the young people. For example, one line of social and cultural distinction between young people is the way they perceive Frankfurt's main shopping street, the "Zeil". For some, it is a space for meeting friends and going shopping together while for others "it seems hours away", not only because of the long underground ride there from their neighbourhood, but also because the social segregation of some quarters leads to certain lock-in effects for the less privileged parts of the city.

Another example is the meaning of youth clubs and youth centres. For young people from group discussions in Gymnasiums, one statement is typical: "the [youth club] is for other people, not for us. We don't need that kind of thing". Other less educationally privileged groups talk about the local youth club as their "home", a highly valued place where you can meet "everyone" and really "belong". Our case study in one inner-city youth centre confirmed this overall estimation. It is mainly used by young people from less affluent neighbourhoods and lower parts of the three-tier educational system. The scarcity of the resource "open youth space" - compared to the music, dance and other leisure offers organised by the youth workers - leads to a constant renegotiation of "who owns the place" between different cliques and scenes. In the attempts of the regular visitors to 'occupy' the open area, the need and the necessity of an own, identificatory space, in which they can constantly experiment with self-dramatization and positioning, is expressed in equal measure. The young people who use the project offers, on the other hand, must constantly update the type of use and the work alliance on call. This requires a high level of interaction from both professionals and visitors. When 
all those using the facility meet, a conflict over forms of participation becomes clear: prestigious participation offerings are rejected by regular visitors and their attempts to participate are (dis)evaluated by the experts as "doing nothing" and perceived as disturbing.

A third example is the youth parliament organised by the Municipality. The Youth and Student Forum (YSF) is an elected body, legally framed and integrated into a nationwide network of representative structures from the local to the federal level. The YSF is housed in an office in the city centre and consists of a board of directors, speakers and a committee of supporters. An adult volunteer takes over part of the bureaucratic activities, ensures continuity and knowledge transfer and acts in an advisory capacity. The city administration provides the YSF with an annual budget, which is used for campaigns and projects and has recently even been increased. The activities of the YSF include committee work, representation of the interests of young people regarding the city administration and politics as well as in working groups, it carries out thematic projects and combines nationwide networking and work "on the ground". In the process, questions about the legitimacy vis-à-vis the city administration and the young people in the city, who often do not even know about the YSF, arise time and again. In addition to low voter turnout, representativeness is also limited by a lack of diversity. The young members reflect self-critically on the fact that the YSF is primarily recruited from upper secondary school students. Since the representatives are elected in the schools, the active members see access and representation as limited by age-related and school-based selection factors. Younger pupils are not yet interested in this form of engagement and from the upper school onwards, half of the pupils are in the vocational or company-based education and training system with its own time structure. The core group of this device is composed of students from Gymnasium. A participant observation at the general assembly of pupils and student representatives from all Frankfurt schools, where this core group was elected allowed us to assist to how subtly exclusion and the self-selection processes work together to construct the bias towards better-off students from the higher ranks of the Frankfurt educational landscape. One of the more obvious mechanisms is that the core group meetings are always scheduled in the early afternoon - a time when students from vocational schools or young people doing in-company training cannot usually participate. For the active members themselves, participation in the Forum is a valuable learning process in terms of political socialization and the development of career perspectives. The formalised framework provides both a safe place for trying things out in formal structures and a limit to activities. Formal participation structures, in particular, must first be acquired and processes of working through them require a large amount of time and energy in the search for "the right political work".

\section{Conclusion}


The two cases presented in the previous sections have to be interpreted according to the national economic and historical frameworks in which they are embedded, which have brought to different institutional interpretations of youth and therefore to the youth policies targeted to them. From their side, young people in the two countries have reacted (differently?) to the political, economic and educational situations that they were confronted with, developing forms of engagement and participation, which assume either the conformist form of "being in society" when this last offers inclusion's possibilities although of different social status (the German case) or the antagonist form of "rejecting society" when the latter neglects the need and instances coming from young people themselves (the Italian case). In the following, we sum up how the structural differences existing in the two cities have brought about different responses by the young people.

The overall difference between the two cities is the different backing of youth policies in the contextual situation in their respective countries. Whether this can be linked to the concept of welfare regimes, a concept adapted to youth policies by Walther (2006), is still an object of ongoing debates (Walther et al., 2021). While the Italian sub-protective welfare regime is centred around the family or better the male "breadwinner", most of the political action in the employment-centred German regime is targeting the individual as a (potential) employee. This difference reflects the different levels of responsiveness of the two labour markets, whose differences have even more deepen. in the aftermath of the economic crisis of 2008. While the crisis has not hit the German labour market in any substantial way, it has in Italy and those affected are especially the young people, who become "particularly vulnerable in the face of a recession compared with adult ones and that this volatility in youth unemployment is due to the low level of employment protection for young people" (Liotti, 2020: 160) for whom the family is expected to provide. While the unemployment rate among young people in Germany in June 2020 amounts to $5.6 \%$, in Italy it was $27.6 \%$ (source: https://www.statista.com/statistics/266228/youth-unemployment-rate-in-eu-countries).

Lacking any national general law on youth and in front of the ongoing reduction of the financial resources assigned to the National Fund for Youth Policies, in Bologna, the Municipality has historically tried to promote participative youth policies that are now suffering under frequent budget cuts imposed by the crisis, on the one side (Andersson et al., 2016). On the other side, having to face the disaffection if not the hostility of many young people for the representative forms of participation perceived as a tokenist form of control (see above the opinion of our respondents), the Municipality dismissed the idea of Youth Council in 1998. Trying to comply with youth preference to engage in self-managed and self -organized engagement activities, local institutions are now mostly playing the role of "sponsors" of youth initiatives. In fact, the Municipality of Bologna does not envisage direct 
forms of consultation and involvement of young people in its administrative and governmental organs, but it acts according to subsidiarity principles, supporting either with funds or spaces youth's experiences of self-activation and initiatives from third sector associations aimed at fostering youth engagement. It must be said that young people have often achieved a negotiation power with the Municipality through protests and squatting actions and only after that the local government considered the opportunity of following or repressing the initiative, also listening to the voice of the public opinion.

In Frankfurt, the "employment-centred" regime type can be felt by the strong corporatism that is governing the welfare system. This system is able to absorb certain conflicts and pacify them through welfare and youth organizations. Some of these have roots in left-wing social movements, but have undergone a long process of professionalization, which has led to a representative democratic type of governance that also structures the field of youth policies. The price to be paid compared to Bologna is a de-politicization of youth policies and related to this, the mutual ignorance of left-wing student scenes and local youth policies. Still, the institutionalization of open youth work as a mainstream offer is able to establish social integration processes in Frankfurt that are completely lacking for Bologna. Further research should look into its role in keeping the potential for youth protests against the educational system, one topic that has been mobilising young people in Bologna just last year. It is all the more memorable that this is seldom the case in Frankfurt given the fact that according to educational research, the German education system is comparably bad at balancing social inequalities. At the same time, as a global city and financial hub, Frankfurt has been one of the hotspots of the Blockupy movement in the aftermath of the financial meltdown in 2012/13 (Mullis et al., 2016).

The growing influence of activating welfare as a national trend nevertheless has altered local youth policies in both cases in a way to focus on the self-responsibility of young people, running the risk of concealing all structural causes in a neoliberal ideology of the self-responsible individual (Lopez Blasco et al., 2003; Castel \& Duvoux, 2013; Loncle, 2013; Meuth et al., 2014). Local youth policies, are dealing with these positionings of young people without adopting a clear integrated approach, as they still are highly fragmented, both decentralized and devolved, split between a large number of public actors (cf. Wallace \& Bendit, 2009; Cuconato, 2020), who - organized in a 'silo' manner fail in promoting "integrated youth policies" (cf. López Blasco et al., 2003; Siurala, 2005). In this way, they are regarded as unable to close the gap between differences within the youth life condition, persisting in the mainstream interpretations of young people, either as a problem or as a resource 
(Gazit \& Perry-Hazan, 2020) instead of tackling the very tangible consequences of the "broken promises" to the younger generations, at least in Italy (Brown et al., 2011).

\section{References}

Andersson, B., Cuconato, M., De Luigi, N., Demozzi, S., Forkby, T., Ilardo, M., Martelli, A., Pitti, I., Tuorto, D., and Zannoni, F. (2016). National Contexts of Youth Participation. Comparative Report. PARTISPACE Working Papers. DOI: 10.5281/zenodo.48113

Baldissara, L. (1994). Per una città più bella e più grande. Il governo municipale di Bologna negli anni della ricostruzione 1945-1956. Bologna: Il Mulino.

Bazzanella, A., and Campagnoli, G. (2014) Giovani e politiche giovanili in Italia, Autonomie locali e servizi sociali, Quadrimestrale di studi e ricerche sul welfare 3/2014, pp. 379-402.

Becquet, V., Kovacheva, S., Popivanov, B., and Forkby, T. (2020). Discourses of youth participation in Europe. National and transnational perspectives. In A. Walther, J. Batsleer, P. Loncle, and A. Pohl, eds., Young People and the Struggle for Participation: Contested Practices, Power and Pedagogies in Public Spaces, London: Routledge, pp. 34-48.

Brown, P., Lauder, H., and Ashton, D. N. (2011). The global auction: The broken promises of education, jobs, and incomes. Oxford: Oxford Univ. Press.

Burns, J. (2001). Fragments of impegno. Interpretations of Commitment in Contemporary Italian Narrative. 1980-2000. Leeds: Northern Universities Press.

Campagnoli, G. (2010). Storia, promesse e linee di sviluppo delle politiche giovanili in italia. RICERCAZIONE 299.

Capponi, M., ed. (1989). Studenti a Bologna 1967-1968. Bologna: Istituto Gramsci EmiliaRomagna.

Casadei, M., and Finizion, M. (2021). Le Province più vivibili d' Italia. Qualità della vita 2020. Il Sole 24 Ore, online. Retrieved 08.02.2021 from https://lab24.ilsole24ore.com/qualita-della-vita.

Castel, R., and Duvoux, N. (Eds) (2013). L'avenir de la solidarité. Paris: PUF.

Censis. (2003). Bologna oltre il benessere. Milano: FrancoAngeli.

CDEJ (2003). Experts on Youth Policy Indicators, Final Report. Council of Europe: Strasbourg.

Colombo, A. Vanelli, V. (2012). Cittadinanza e partecipazione - Rapporto per il Piano Strategico Metropolitano. $\quad$ Retrieved 08.02 .2021 from https://psm.bologna.it/Engine/RAServeFile.php/f/Tavoli/report-vanelli_logo.pdf

Cuconato, M. (2020). Youth Participation in Europe: The interplay between Discourse and Policies. In: X. Úcar, P. Soler-Masó, and A. Planas-Lladó, eds., Working with young people: A social pedagogy perspective from Europe and Latin America, Oxford, Oxford University Press, pp. 96112.

Dahl, V., Amnå, E., Banaji, S., Landberg, M., Šerek, J., Ribeiro, N., Beilmann, M., Pavlopoulos, V., and Zani, B. (2018). Apathy or alienation? Political passivity among youths across eight European Union countries. European Journal of Developmental Psychology, 15(3), 284-301.

Della Porta, D. (2015). Social Movements in Times of Austerity: Bringing Capitalism Back Into Protest Analysis. Cambridge: Polity Press.

Donati, P., Colozzi, I., and Bologna, E. D., eds. (2002). Religione, società civile e stato: quale progetto?. Edizioni Dehoniane Bologna.

Dozza, G. (1987). Il buon governo e la rinascita della città. Scritti 1945-1966. Bologna: Nuova Universale Cappelli.

Furlong, A., and Cartmel, F. (2007). Young people and social change new perspectives. Maidenhead: McGraw-Hill/Open University Press.

Gazit, M., and Perry-Hazan, L. (2020). Disadvantaged youth's participation in collective decision making. Children and Youth Services Review 110. DOI: 10.1016/j.childyouth.2020.104759

Giddens, A (1991). Modernity and Self-Identity: Self and Society in the Late Modern Age. Cambridge: Polity Press. 
Hall, S., Jefferson, T., Clarke, J., and Roberts, B. (1976). Subcultures, cultures and class. In: S. Hall, and T. Jefferson, eds., Resistance through rituals: Youth subcultures in post-war Britain, London: Hutchinson, pp. 14-15.

Harvey, D (2003). Young People in a Globalizing World. New York: World Youth Report.

Jäggi M., Müller R., and Schmid S. (1977). Bologna rossa. I comunisti al governo di una città. Milano: Feltrinelli.

Jones, G. (2009). Youth. Cambridge; Malden, MA: Polity.

Liotti, G. (2020). Labour market flexibility, economic crisis and youth unemployment in Italy. Structural Change and Economic Dynamics, 54, 150-162.

Loncle, P. (2013). La diversité des valeurs des politiques publiques s'adressant à la jeunesse : quelles conséquences pour la prise en compte sociale de cette population? Congrès de l'association française de sociologie, Nantes.

Loncle, P., Cuconato, M., Tuorto, D. and Andersson, B. (2020). Do youth policies matter? National and local youth policies as contexts of Youth participation. In: A. Walther, J. Batsleer, P. Loncle, and A. Pohl, eds., Young People and the Struggle for Participation: Contested Practices, Power and Pedagogies in Public Spaces, London: Routledge, pp. 49-64.

López Blasco, A., McNeish, W., and Walther, A., eds. (2003). Young people and contradictions of inclusion: towards Integrated Transition Policies in Europe. Bristol: Policy Press.

Lütgens, J., Mengilli, Y., Pohl, A., Schwanenflügel, L. von, and Walther, A. (2017). PARTISPACE National Country Report WP4 Frankfurt/Germany. Goethe-University of Frankfurt/Main.

Mayo, M. (2005). Global Citizens: Social Movements and the Challenge of Globalisation. London: Zed Books.

Meuth, M., Warth, A., and Walther, A. (2014). No crisis but a paradigm shift? German youth policy between continuity and change. International Journal of Adolescence and Youth 19 (sup1), pp. 79-92. DOI: 10.1080/02673843.2013.813860.

Miles, S. (2000). Youth Lifestyles in a Changing World. Maidenhead: Open University Press.

Montanari, F. (1996). I servizi per i giovani in Italia e i centri di Informazione. In L. Guerra, F. Hamburger and L. Robertson, eds., Educazione comunitaria in Europa. Dimensioni interculturali del lavoro con i giovani, Bergamo: Junion. pp. 182-192.

Mullis, D., Belina, B., Petzold, T., Pohl, L., and Schipper, S. (2016). Social protest and its policing in the "heart of the European crisis regime": The case of Blockupy in Frankfurt, Germany. Political Geography 55, pp. 50-59. DOI: 10.1016/j.polgeo.2016.07.001

Pilkington, H. and Johnson, R. (2003). Peripheral Youth. European Journal of Cultural Studies 6 (3), pp. 259-283.

Piro, V., De Luigi, N., Reutlinger, C., and Zimmermann, D. (2020). Making a home in the city: how young people take part in the urban space. In: A. Walther, J. Batsleer, P. Loncle and A. Pohl, eds., Young People and the Struggle for Participation: Contested Practices, Power and Pedagogies in Public Spaces, London: Routledge, pp. 97-112.

Rapini A. (1999). Tra università, piazze e fabbriche: cronologia del movimento studentesco bolognese (1967-1969). In: Adagio, C., ed., Tra immaginazione e programmazione: Bologna di fronte al '68. Materiali per una storia del '68 a Bologna, Milano, Edizioni punto rosso.

Schwanenflügel, L. von, and Walther, A. (2016). 'Verjugendsozialarbeiterisierung' oder Infrastruktur der Anerkennung? Kinder- und Jugendhilfe im aktivierenden Wohlfahrtsstaat. In: M. Zipperle, P. Bauer, B. Stauber, and R. Treptow, eds., Vermitteln, Wiesbaden: Springer Fachmedien, pp. 309-322.

Siurala, L. (2005). A European Framework for Youth Policy. Strasbourg: Council of Europe.

Smith, M. K., Leschke, J., Russell, H., and Villa, P. (2019). Stressed economies, distressed policies, and distraught young people: European policies and outcomes from a youth perspective. In J. O'Reilly, J. Leschke, R. Ortlieb, M. Seeleib-Kaiser, and P. Villa, eds., International policy exchange series. Youth labor in transition: Inequalities, mobility, and policies in Europe New York, NY: Oxford University Press, pp. 104-131. 
Steinacker, S. (2017). Heimerziehung und die politischen Kämpfe der 68er-Bewegung. In R. Braches-Chyrek, and H. Sünker, eds., Soziale Arbeit in gesellschaftlichen Konflikten und Kämpfen. Wiesbaden: Springer VS, pp. 245-263.

Templin, D. (2015). Freizeit ohne Kontrollen: Die Jugendzentrumsbewegung in der Bundesrepublik der 1970er Jahre. Hamburger Beiträge zur Sozial- und Zeitgeschichte: Band 52. Göttingen: Wallstein Verlag.

Troilo, M. (2013). Bologna e il Welfare locale, appunti per una storia, E-Review. Rivista degli Istituti Storici dell'Emilia-Romagna in Rete 1. DOI: 10.12977/ereview41

Wacquant, L. (2004). Punir les pauvres: le nouveau gouvernement de l'insécurité sociale. Marseille: Agone.

Walther, A. (2012). Participation or non-participation? Getting beyond dichotomies by applying an ideology-critical, a comparative and a biographical perspective. In: P. Loncle, M. Cuconato, V. Muniglia, and A. Walther, eds., Youth participation in Europe: Beyond discourses, practices and realities, Bristol: Policy Press., pp. 227-244.

Walther, A., Batsleer, J., Loncle, P., and Pohl, A., eds. (2020a). Young People and the Struggle for Participation: Contested Practices, Power and Pedagogies in Public Spaces. London: Routledge.

Walther, A., Pohl, A., Loncle, P. and Thomas, N. P. (2020b). Researching youth participation theoretical and methodological limitations of existing research and innovative perspectives. In: A. Walther, J. Batsleer, P. Loncle, and A. Pohl, eds., Young People and the Struggle for Participation: Contested Practices, Power and Pedagogies in Public Spaces, London: Routledge, pp. 15-33.

Walther, A., Lüküslü, D. G., Loncle, P. and Pais, A. (2021). Regimes of Youth Participation? Comparative Analysis of Youth Policies and Participation across European Cities. Young 29(2), pp. 191-209.

Williamson, H. (1997). Youth and policy: contexts and consequences. Aldershot: Ashgate. 